\title{
OPTIMUM PROTEIN AND ENERGY LEVELS FOR LAYER CHICKENS IN THE HUMID TROPICS
}

\author{
F. C. OBIOHA and IFEOMA ONYILIOGWU \\ Department of Animal Science, University of Nigeria, Nsukka, Nigeria.
}

\begin{abstract}
IN a study involving 12 diet combinations with 3 energy levels (2.6-3.0 Mcal $/ \mathrm{kg}$ ME), 4 protein levels $(14 \%-20 \%)$ and 12 calorie-protein ratios (13.13-19.68 Kcal/gm protein) layer chickens performed significantly better on a $3.0 \mathrm{Mcal}-18.45 \%$ protein diet $\left(E_{3.0} P_{18.45}\right)$ than any other diet, in egg number, egg weight, feed efficiency, protein efficiency ratio, revenue-cost ratio and egg number -. feed cost ratio. Average daily feed consumption was $90 \mathrm{~g}$. Diets coresponding to N.R.C. levels of $E_{2.85} P_{15}$ supported less than 280 Kcal ME or 16.55 g protein daily intake, respectively, and were inferior to the $\mathbf{E}_{3.0} \mathbf{P}_{18.45}$ diet.
\end{abstract}

\section{INTRODUCTION}

Reports from literature indicate that laying hens in a tropical environment may have higher protein requirements than those in the temperate environments (Chawlar et al 1976). Harms et al. (1962) reported that laying hens in the summer months had higher protein requirements than those in the winter. Davis et al (1973) also reported a drop of $1 \mathrm{~g}$ dry matter feed intake and 2.7 Kcal ME per bird per day for each degree centigrade rise in temperature. A fundamenal question arises as to whether the tropical factor as it affects feed intake and layer productivity in general, is an isolated temperature effect or whether it is a composite of several factors which impose on layers the need for a different requirement from those in the temperate environments?

Attempts to increase feed consumption in chickens by a reduction of energy content in feeds (Harms et al 1962), by fibre dilution or feed restriction (Lillie et al 1966) have resulted in low productivity and high mortality arising from poor utilization of dietary protein. Because protein in energy are closely related, changes in one nutrient demand ad- justments in the other, to ensure optimal utilization of both nutrients (Khoo 1977).

The objectives of this study are to investigate the optimum levels and ratios of protein and energy for layer chicks in a humid tropical environment, and to ascertain if such levels necessarily differ from adjusted levels based on observed intake.

\section{MATERIALS AND METHODS}

One hundred and ninety two Gold Link $579 \mathrm{~F}_{1}$ layer were used in this experiment. They were previously hatched in 3 batches within February 1981, came into lay in August and were put on experimental diets in November 1981.

Before the experiment started, the birds had received all necessary vaccinations and were dewormed with Furaprol. The birds were housed two per cage in 3 tier cages which had been washed and disinfected with Izal.

Twelve experimental diets containing four protein levels $(14,16,18$ and $20 \%$ ) and three energy levels $(2,6,2.8$ and 3.0 Mcal/kg ME) were formulated by varying proportions of maize $(10 \% \mathrm{CP})$ groundnut cake $(45 \% \mathrm{CP})$, rice bran $(12 \% \mathrm{CP})$, brewers dry gains $(21 \% \mathrm{CP})$ and fish meal $(62 \%$ CP) (Tables 1 and 2). Identical levels of oyster shell, bone meal, common salt and a vitamin-mineral premix were added to each of the twelve treatment diets. Palm oil was added where necessary to boost the energy content of the diets especially in the 2.8 and $3.0 \mathrm{Mcal} / \mathrm{kg}$ diets. These various combinations resulted in 12 calorie-protein ratios varying from 13.0 to $21.43 \mathrm{Mcal} / \mathrm{gm}$ protein. The feed ingredients had previously been analysed for protein and energy, on the basis of which the diet formulations were calculated. The diet components were

Nigerian Journal of Animal Production 9(2) 1982. 
OBIOHA ET $A L$

TABLE 1

Composition of Experimental Diets

\begin{tabular}{lcccccccccccc}
\hline & \multicolumn{10}{c}{ Diets } \\
\hline Ingredients \% DM & 1 & 2 & 3 & 4 & 5 & 6 & 7 & 8 & 9 & 10 & 11 & 12 \\
\hline Maize & 50 & 60 & 64 & 50 & 50 & 55 & 50 & 66 & 56 & 50 & 50 & 52 \\
Groundnut cake & 10 & 10 & 12 & 14 & 15 & 16 & 18 & 20 & 22 & 20 & 22 & 24 \\
Rice Bran & 12 & 8 & - & 11 & 7 & 4 & 6 & - & - & - & - & - \\
Spent Grains & 14 & 8 & 6 & 10 & 10 & 5 & 10 & 5 & - & 11 & 7 & - \\
Fish Meal & 3 & 3 & 3 & 4 & 4 & 4 & 5 & 5 & 6 & 8 & 8 & 8 \\
Oyster shell & 7 & 7 & 7 & 7 & 7 & 7 & 7 & 7 & 7 & 7 & 7 & 7 \\
Bone Ash & 3 & 3 & 3 & 3 & 3 & 3 & 3 & 3 & 3 & 3 & 3 & 3 \\
Palm Oil & - & - & 4 & - & 3 & 5 & - & 4 & 5 & - & 2 & 5 \\
Common Salt & 0.5 & 0.5 & 0.5 & 0.5 & 0.5 & 0.5 & 0.5 & 0.5 & 0.5 & 0.5 & 0.5 & 0.5 \\
Mineral-Vitamin Premix & 0.5 & 0.5 & 0.5 & 0.5 & 0.5 & 0.5 & 0.5 & 0.5 & 0.5 & 0.5 & 0.5 & 0.5 \\
\hline
\end{tabular}

${ }^{1}$ Zoodry UM 301 for Laying Hens contains in $0.15 \%$ :

Vit A (Stabilized)

Vit D (Stabilized)

Vit $E^{3}$ (Stabilized)

Menadione Sodium bisulfite

Vit $\mathrm{K}$

Vit $\mathbf{B}_{2}$

Vit $\mathrm{B}_{6}$

Niacin

Calcium d-pantothsnate

$6670,000 \mathrm{IU}$
$1340,000 \mathrm{IU}$
$6670 \mathrm{IU}$
$1340 \mathrm{mg}$
$1340 \mathrm{mg}$
$3000 \mathrm{mg}$
$2000 \mathrm{mg}$
$16,670 \mathrm{mg}$
$5,340 \mathrm{mg}$

$6670,000 \mathrm{IU}$

$6670 \mathrm{IU}$

$340 \mathrm{mg}$

$3000 \mathrm{mg}$

ming

$5,340 \mathrm{mg}$

$\begin{array}{rr}\text { Vit } \mathrm{B}_{12} & 13,340 \mathrm{mg} \\ \text { Vit } \mathrm{C} & 133,400 \mathrm{mg} \\ \text { Choline Chloride } & 66,670 \mathrm{mg} \\ \text { Manganese } & 33,340 \mathrm{mg} \\ \text { Iron } & 26,670 \mathrm{mg} \\ \text { Copper } & 1,600 \mathrm{mg} \\ \text { Iodine } & 934 \mathrm{mg} \\ \text { Cobalt } & 134 \mathrm{mg} \\ \text { Selenium } & 34 \mathrm{mg}\end{array}$

ground, weighed and thoroughly mixed.

The experimental birds were randomly distributed into the cages to which experimental diets were assigned. Preliminary feeding with experimental diets lasted for 7 days while the actual experiment started on January 8, 1982 when the birds were averaging $51 / 2$ months in lay. Feed and water were provided $a d$ libitum; the excess feed was collected and weighed back every week while the unused water was measured in a measuring cylinder every day. Eggs were collected twice daily, 11 a.m. and 4 p.m. and the number and weights recorded. The experiment lasted for 56 days after which the birds were thinned to one per cage for total faecal collection which was used to calculate dry matter digestibility and nitrogen retention. This collection lasted 5 days.
Data were processed and statistically analysed according to a $3 \times 4$ factorial design (Steel and Torrie, 1960) for each of the following parameters: egg yield, egg weight, feed intake, metabolisable energy intake, crude protein intake, feed conversion ratio, dry matter digestibility, nitrogen retention and protein efficiency ratio. Where means were found significantly different, such differences were identified using Duncan's Multiple Range Test as described by Steel and Torrie (1960). Proximate analyses of the feeds and faeces were done according to the A.O.A.C. methods (1970).

Egg revenue and feed cost analysis were carried out as a basis for identifying optimum levels of nutrients as distinct from levels of highest response obtained in the results. 
OBIOHA ET $A L$

TABLE 2

Proximate and Chemical Composition of Experimental Diets ( $\%$ of Dry Matter)

\begin{tabular}{|c|c|c|c|c|c|c|c|c|c|c|c|c|}
\hline \multicolumn{13}{|c|}{ Diets } \\
\hline & 1 & 2 & 3 & 4 & 5 & 6 & 7 & 8 & 9 & 10 & 11 & 12 \\
\hline Crude Protein \% & 14.09 & 14.23 & 14.18 & 16.41 & 16.63 & 16.16 & 18.59 & 18.16 & 18.45 & 20.35 & 20.18 & 19.82 \\
\hline Ether Extract $\%$ & 6.35 & 8.80 & 9.25 & 4.95 & 8.90 & 8.90 & 6.30 & 8.75 & 8.70 & 5.90 & 7.50 & 10.25 \\
\hline Crude Fibre \% & 6.00 & 4.95 & 4.65 & 5.24 & 5.73 & 4.32 & 5.50 & 4,30 & $4.4{ }^{2}$ & 4.67 & 4.85 & 3.50 \\
\hline Ash \% & 11.70 & 12.00 & 9.10 & 10.50 & 11.35 & 12.70 & 11.60 & 11.20 & 10.80 & 12.80 & 12.30 & $10 . \%$ \\
\hline NFE $\%$ & 61.86 & 60.02 & 62.82 & 62.90 & 57.39 & 57.92 & 58.01 & 57.59 & 57.60 & 56.28 & 55.17 & 55.53 \\
\hline
\end{tabular}

Calculated Composition:

\begin{tabular}{lcccccccccccc}
$\begin{array}{l}\text { Metabolisable Energy } \\
\text { (Mcal/kg) }\end{array}$ & 2.68 & 2.80 & 3.00 & 2.58 & 2.83 & 3.02 & 2.69 & 2.80 & 3.03 & 2.67 & 2.81 & 3.00 \\
& & & & & & & & & & & & \\
& & & & & & & & & & & & \\
Lysine \% & 0.61 & 0.56 & 0.60 & 0.67 & 0.67 & 0.64 & 0.76 & 0.73 & 0.76 & 0.90 & 0.90 & 0.87 \\
Methionine + Cystine \% & 0.55 & 0.52 & 0.51 & 0.59 & 0.59 & 0.57 & 0.65 & 0.63 & 0.64 & 0.75 & 0.74 & 0.71 \\
\hline
\end{tabular}

\section{RESULTS}

The performance of the layer hens in response to the dietary treatments is summarised in table 3.

Egg yield was significantly increased as protein levels increased $(\mathrm{P}<0.05)$ but increases in egg numbers as a result of increases in dietary energy were not significant $(\mathrm{P}<0.05)$. The highest number of eggs was supported by diet 9 (3.03 $\mathrm{Mcal} / \mathrm{kg} \quad 18.45 \%$ protein) while the least number of eggs was produced by diet 1 $(2.68 \mathrm{Mcal} / \mathrm{kg} \quad 14.09 \%$ protein). Both values different significantly ( $P(0.05)$. Each of diets 1 and 2 produced significantly fewer eggs than each of diets $5,8,9,10,11$ and 12 , while diets $3,4,6$ and 7 came in between and were significantly not different from any of the two groups of diets $(P>0.05)$.

Egg weights were also maximised in diet 9 and were least in diets 1 and 2 , following exactly the same trend as egg numbers.

Feed consumption was highest in diet 5 but no significant difference was observed among any of the treatments. Diets 1 and 2 again supported the least feed consumption.

Feed consumed per unit of egg produc- tion ( $\mathrm{kg}$ feed $/ \mathrm{kg} \mathrm{egg}$ ) was significantly affected by protein levels ( $P<0.01)$ but not by energy levels $(P>0.05)$. The highest feed efficiency value was in diet 12 while the poorest was in diet 2 .

Protein efficiency ratio, measured as $\mathrm{kg}$ egg produced per $\mathrm{kg}$ protein intake showed no significant variation among the diets $(P>0.05)$ as a result of changes in energy or protein content. The highest value was recorded in diet 9 while the least was in diet 2.

Dry matter digestibility appeared to increase linearly and significantly with both protein and energy increases (P $\triangle \Delta .01)$. The most digestible diet was 3 while the least was 10 .

Nitrogen retention was significantly increased by increases in protein levels $(P \angle 0.01)$ but not by increases in energy levels. The highest value was diet 12 which also contained the highest level of protein and energy. The least was diet 2.

Metabolisable energy intake peaked in diet 6 which contained $3.02 \mathrm{Mcal} / \mathrm{kg} \mathrm{ME}$ and $16.16 \%$ protein. The least ME intake was diet 1 . Protein intake was highest in diet $10\left(\mathrm{E}_{2.68} \mathrm{P}_{14.09}\right)$.

Cost-benefit data, derived from the 


\section{OBIOHA ET AL}

TABLE 3

The Response of Layers to Diet Treatments

\begin{tabular}{|c|c|c|c|c|c|c|c|c|c|c|c|c|}
\hline \multicolumn{13}{|c|}{ Diets } \\
\hline & 1 & 2 & 3 & 4 & 5 & 6 & 7 & 8 & 9 & 10 & 11 & 12 \\
\hline Protein $\quad \% \quad 19.82$ & 14.23 & 14.18 & 16.41 & 16.63 & 16.16 & 18.59 & 18.18 & 18.45 & 20.35 & 20.35 & 20.18 & 19.82 \\
\hline $\begin{array}{l}\text { Metabolizable Energy } \\
(\mathrm{Mcal} / \mathrm{g})\end{array}$ & 2.68 & 2.80 & 3.00 & 2.68 & 2.83 & 3.02 & 2.69 & 2.80 & 3.03 & 2.67 & 2.81 & 3.00 \\
\hline $\begin{array}{l}\text { Calorie-Protein Ratio } \\
\text { (Kcal/g Protein) }\end{array}$ & 19.02 & 19.68 & 21.16 & 16.33 & 17.02 & 18.69 & 14.47 & 15.42 & 16.42 & 13.12 & 13.92 & 15.14 \\
\hline
\end{tabular}

$\begin{array}{llllllllllllll}\text { Egg number per week } & 1.71^{\mathrm{b}} & 1.73^{\mathrm{b}} & 2.60 & 2.64 & 3.15^{\mathrm{ab}} & 3.01 & 2.40^{\mathrm{b}} & 3.1^{\mathrm{b}} & 3.74^{\mathrm{a}} & 3.50^{\mathrm{a}} & 3.20^{\mathrm{a}} & 3.70^{\mathrm{a}}\end{array}$ per bird

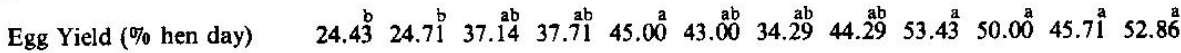
Egg weight per week per $103.25^{\mathrm{b}} 103.74_{157.42}^{\mathrm{b}} 155.08199 .94^{\mathrm{a}} 184.52 \mathrm{~b} 143.61^{\mathrm{a}} 194.06^{\mathrm{a}} 222.088^{\mathrm{a}} 215.27^{\mathrm{a}} 192.85^{\mathrm{a}} 220.93$ bird ( $\mathrm{g})$

Feed intake per week/bird

(g)

\section{$\mathrm{Kg} \mathrm{Feed/kg} \mathrm{Egg}$}

Protein Efficiency Ratio

P.E.R.

Nitrogen Retention g/day

DMD \%

Protein Intake $g /$ day
539.50 598.94 615.47626.32696.42670.82 665.07617.15 632.68648.95619.24625.90

$\begin{array}{rrrrrrrrrrrr}5.64 & 6.01 & 4.06 & 5.26 & 4.06 & 3.90 & 4.83 & 3.22 & 3.05 & 3.16 & 3.22 & 2.98\end{array}$ $\begin{array}{llllllllllll}1.36 & 1.22 & 1.80 & 1.51 & 1.73 & 1.70 & 1.16 & 1.73 & 1.90 & 1.63 & 1.54 & 1.78\end{array}$

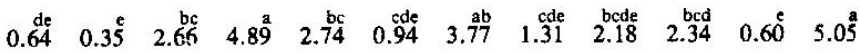

\begin{tabular}{llllllllllllll} 
M.E. Intake Mcal/day & 0.21 & 0.24 & 0.27 & 0.24 & 0.29 & 0.26 & 0.25 & 0.28 & 0.25 & 0.25 & 0.27 & abc \\
\hline
\end{tabular} a,b,c. Means of a parameter followed by a common superscript are significantly not different at $5 \%$ level. * $=\mathrm{P}<0.05 ; \quad * *=\mathrm{P}<0.01 ; \quad * * *=\mathrm{P}<0.005$.

Mean S.E.

\begin{tabular}{rr}
\hline 2.87 & $0.406^{*}$ \\
39.97 & $2.59^{*}$ \\
174.40 & $26.22^{*}$ \\
629.71 & $41.49^{*}$ \\
4.12 & $0.77^{*}$ \\
1.62 & $0.23^{*}$ \\
2.29 & $0.47^{*}$ \\
70.03 & $1.35^{*}$ \\
15.58 & $0.89^{*}$ \\
0.26 & $0.012^{*}$ \\
\hline
\end{tabular}

performance of layers on the the twelve diets and the cost of the diets, are presented in Table 4. From this table egg number per unit of feed.cost, egg revenue 
OBIOHA ET $A L$

TABLE 4

Cost-Benefit Comparison of Experimental Diets

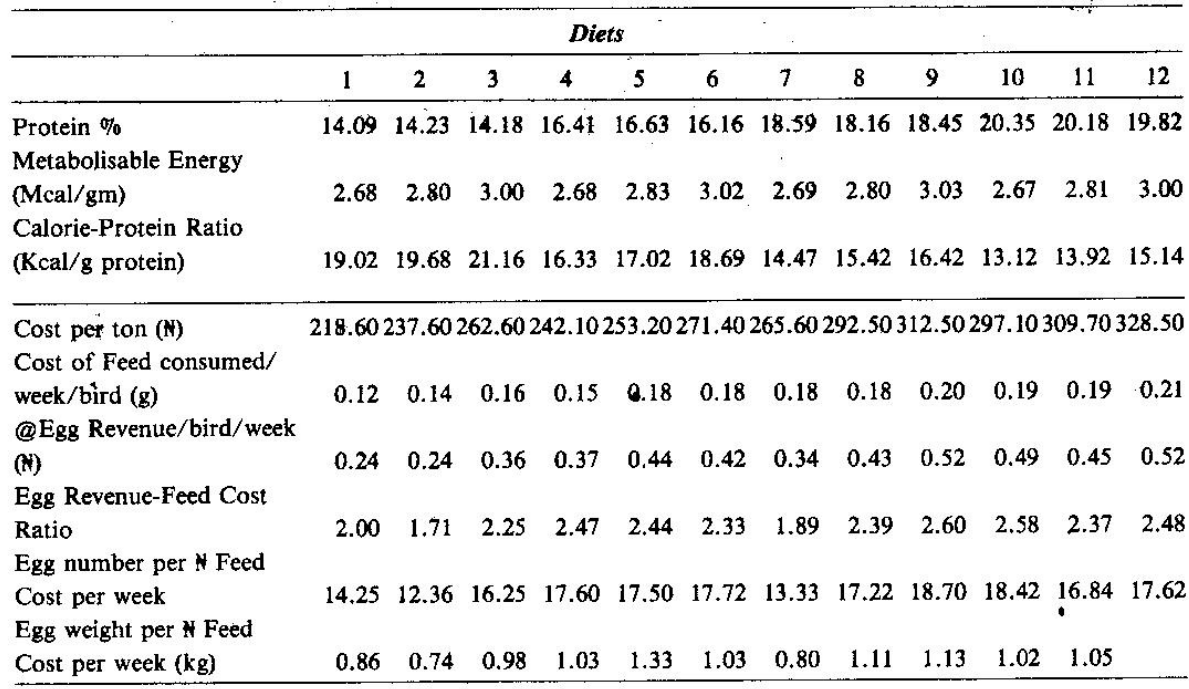

per unit of feed cost and egg revenue were all maximised in diet 9. However, egg weight per unit of feed cost was highest in diet.

The interacting effect of energy and protein are included in the responses of layer chicks presented in Table 3. The separate energy and protein effects as they relate to the same parameters are summarised in Tables $5 \mathrm{a}$ and $5 \mathrm{~b}$ respectively. In Table 5a, all nine response parameters except nitrogen retention and protein intake appeared to improve linearly as energy value of the diet was increased from 2.6 to $3.0 \mathrm{Mcal} / \mathrm{kg}$. Nitrogen retention decreased sharply between 2.6 and $2.8 \mathrm{Mcal} / \mathrm{kg}$ values and rose again at the $3.0 \mathrm{Mcal} / \mathrm{kg}$ level. Average protein intake on the other hand remained generally uniform in the 3 energy levels but reached its highest point at the $2.8 \mathrm{Mcal} / \mathrm{kg}$ level.

In Table $5 \mathrm{~b}$, increases in dietary protein from $14 \%$ to $20 \%$ resulted in linear increases in the average values of egg number, egg weight, feed efficiency and protein intake. There were initial increases in feed intake, protein efficiency ratio, nitrogen retention and ME intake between 14 and $16 \%$ protein levels and subsequent tailing off at the 18 and $20 \%$ levels. Changes in DMD were the reverse.

\section{DISCUSSION}

Evaluation of the twelve diets based on the response of layer chickens as presented in Table 3 would suggest that the diet containing $3.03 \mathrm{Mcal}$ of Metabolisable energy and $18.45 \%$ crude protein excelled in egg number, egg weight, feed efficiency and protein efficiency ratio. The same diet also proved most efficient in 2 cost-revenue parameters (Table 4). Layer chicken responses to diets in excess of $18 \%$ protein were generally equal to or inferior to that in the $18 \%-300 \mathrm{Mcal}$ diet, irrespective of their energy content. The only exception was nitrogen retention, although the high value observed in diet 12 did not manifest itself in high egg productivity. Diets below $18 \%$ were in many cases inferior to diet 9 . Within the $18 \%$ diets, there appeared to be a clear trend towards increased efficacy as the energy level rose 
OBIOHA ET AL

TABLE 5a

The Response of Layer Chickens to Varying Energy Levels

\begin{tabular}{|c|c|c|c|c|c|c|c|c|c|}
\hline \multicolumn{10}{|c|}{ Energy (Mcal/ $\mathrm{kg}$ ) Metabolizable Energy } \\
\hline . & & & & & $\therefore$ & 2.60 & 2.80 & 3.00 & $s d^{\otimes}$ \\
\hline Egg Number/week ... & .. & .. & .. & .. & .. & 2.56 & 2.80 & 3.26 & 0.29 \\
\hline Egg weight/week (g) . . & .. & .. & .. & .. & .. & 154.30 & 172.65 & 196.24 & 17.17 \\
\hline Feed Intake/week (g) & .. & .. & . & .. & $\ldots$ & 619.96 & 632.94 & 636.22 & 7.02 \\
\hline Feed $\mathrm{kg} / \mathrm{Egg} \mathrm{kg} . . \quad \ldots \quad \ldots$ & & .. & .. & .. & . . & 4.72 & 4.13 & 3.50 & 0.50 \\
\hline Nitrogen Retention g/day.. & . & . $\quad$. & . & . & .. & 1.46 & 1.57 & 1.82 & 0.15 \\
\hline Metabolizable Energy Intak & e Mcal & $1 /$ day ... & . & . & .. & 0.24 & 0.26 & 0.27 & 0.012 \\
\hline Protein Intake g/day/chick & .. & .... & .. & .. & . & 15.75 & 15.83 & 15.80 & 0.033 \\
\hline
\end{tabular}

${ }^{Q_{S}} \mathrm{~S}_{\mathrm{d}}=$ Standard deviation.

TABLE 5b

The Response of Layer Chickens to Varying Protein Levels

\begin{tabular}{|c|c|c|c|c|c|c|c|c|}
\hline \multicolumn{9}{|c|}{ Protein \% } \\
\hline & & & & 14 & 16 & 18 & 20 & sd \\
\hline Egg Number per bird/per wee & & $\cdots$ & $\cdots$ & 2.01 & 2.93 & 3.08 & 3.47 & 0.54 \\
\hline Egg weight per bird/week (g) & . & $\ldots$ & $\ldots$ & 121.47 & 179.85 & 186.58 & 209.68 & 32.50 \\
\hline Feed Intake g/week . . . & . & . . & . & 584.64 & 664.52 & 638.30 & 631.36 & 28.81 \\
\hline Feed $\mathrm{kg} /$ Egg kg $\ldots \ldots \ldots$ & $\ldots$ & . & . & 5.24 & 4.41 & 3.70 & 3.12 & 0.79 \\
\hline Protein Efficiency Ratio . . & . & . & . & 1.46 & 1.69 & 1.64 & 1.67 & 0.09 \\
\hline Hitrogen Retention g/day & $\ldots$ & . & . & 1.22 & 2.86 & 2.42 & 2.66 & 0.64 \\
\hline Dry Matter Digestibility (\%) & . & $\ldots$ & . & 74.25 & 65.32 & 70.53 & 70.01 & 3.17 \\
\hline Metabolizable Energy Intake & $\mathrm{Kea}$ & /day & . & 0.24 & 0.27 & 0.26 & 0.26 & 0.01 \\
\hline Protein Intake g/day. . & . & .. & . & 12.04 & 15.67 & 16.81 & 18.66 & 2.42 \\
\hline
\end{tabular}

from 2.6 to 2.8 and $3.00 \mathrm{Mcal} / \mathrm{kg}$, indication here is that energy levels of 2.6 and $2.8 \mathrm{Mcal} / \mathrm{kg}$ are inadequate to evict optimum performance at $18 \%$ protein level. On the other hand, within the $16 \%$ protein levels optimum diet appears to be diet 5 which has $2.8 \mathrm{Mcal} / \mathrm{kg}$ energy, as manifested by a clear superiority of diet 5 over diets 4 and 6 . This observation strengthens the argument of Khoo, (1977), that energy requirement increases with protein level.

In diets 1,2 and 3, responses were generally low, but there was a consistent and linear increase in the response of chickens such that diet 3 was the best and diet 1 the worst. This suggests that protein and energy were both limiting and under those circumstances, increase in energy would produce a response, as was observed in this study. By contrast diets 10,11 and 12 showed a reverse picture in which energy alone was limiting in relation to the protein level in those diets; thus diet 12 qut-performed diets 10 and 11 in most of the parameters tested. Also a comparison of diets $3,6,9$ and 12 will show that responses appeared to be limited by protein levels until a peak response was reached in diet $9(18.45 \%)$, whereafter a decline was observed. The optimum diet under the conditions of this experiment would appear to lie within diets $4,5,6,7,8$ and 9 . Within this groups, diets 5 and 9 appear to stand out as the two best diets, probably because each diet contains a good balance between energy and protein, with calorie-protein ratios of 17,02 and 


\section{OBIOHA ET $A L$}

$16.42 \mathrm{Kcal} / \mathrm{g}$ protein respectively. Brown, Waving and Squance (1963) had suggested that a ratio of $172 \mathrm{Kcal} / \%$ protein was the ideal calorie-protein ratio for layers. The superiority of diet 9 over diet 5 is obvious, inspite of the high level of feed intake observed in diet 5. There is an indication here that the levels of protein and energy in diet 5 are sub-optimal in comparison with those in diet 9 . Since diets 5 and 2 are closest to the N.R.C. (1977) recommendation of $15 \%$ protein and 2.85 . $\mathrm{Mcal} / \mathrm{kg}$ metabolisable energy, it is a clear indication that laying hens under Nigerian conditions, require higher levels of protein and energy than the N.R.C. recommendation.

The variation in layer response to increases in dietary energy (Table 5a) shows that in all parameters, except protein intake and nitrogen retention, the $\mathbf{3 . 0}$ $\mathrm{Mcal} / \mathrm{kg}$ energy level promoted the highest response. This observation as it affects feed intake is not consistent with the view that high energy levels inhibit feed intake. The logical explanation is that such would be the case if the energy level were excessive. From these indications, the highest energy level in this experiment $(3.0 \mathrm{Mcal} / \mathrm{kg})$ was not excessive in general, and would appear to be optimal for diets containing $18 \%$ protein level.

Layer response to increases in dietary protein (Table 5b) showed linear increases in egg number, egg weight, feed-gain ratio and protein intake. The other parameters showed peaks in the $16 \%$ or $18 \%$ protein level, suggesting that either level was optimal provided the energy was adequate for its optimal utilization.

The relative importance of protein, energy and calories-protein ratio in egg number, egg weight, feed intake and feed efficiency is illustrated by the correlation coefficients shown in Table 6. Egg production appears to be influenced by protein content of the diet $(r=0.78$, $P / 0.01$ ) and negatively influenced by calorie-protein ratio $(\mathrm{r}=0.58$, $P / 0.05$ ), while energy appears to have little or no direct influence on egg production. Egg weight is positively associated with protein $(\mathrm{r}=0.75, \mathrm{P} / 0.01)$ and negatively with calorie-protein ratio $(\mathrm{r}=$ $-0.57, \mathrm{P} / 0.05)$. Energy had no direct influence on egg weight. Feed-egg ratio is negatively associated with protein $(r=$ -0.7 . $P / 0.01$ ) but has no significant association with energy or calorie-protein ratio. Feed intake appears to be unaffacted by protein $(r=0.3)$, energy $(r=$ $0.19)$ or calorie-protein ratio $(r=0.33)$. These trends are in general agreement with the report of Quisenbury and Bradley (1962) who observed that egg production, egg weight and feed efficiency were significantly improved by each in-

TABLE 6

Summary of Correlation Coefficients Between Dietary Variables and Egg Production

\begin{tabular}{|c|c|c|c|c|c|c|c|c|c|c|}
\hline & & & & & & & & $\begin{array}{l}\text { Protein } \\
\text { in Diet }\end{array}$ & $\begin{array}{l}\text { Energy } \\
\text { in Diet }\end{array}$ & $\begin{array}{c}\text { Calorie- } \\
\text { Protein Ratio }\end{array}$ \\
\hline Egg Number .. & .. & . & .. & .. & .. & .. & .. & $0.78^{* *}$ & 0.45 & $-0.58^{*}$ \\
\hline Egg weight & .. & .. & .. & .. & .. & .. & .. & $0.75^{* *}$ & 0.41 & -0.57 \\
\hline \multirow{2}{*}{\multicolumn{2}{|c|}{ Feed kg per Egg kg }} & .. & .. & .. & .. & .. & .. & $-0.75^{* *}$ & 0.48 & 0.53 \\
\hline & & & & & & & & 0.38 & 0.19 & 0.33 \\
\hline
\end{tabular}




\section{OBIOHA $E T$ AL}

crease in dietary protein percent.

Regressions of egg number $(\mathrm{Y})$ on percent protein in diet $\left(\mathrm{X}_{\mathrm{p}}\right)$, metabolisable energy content of diet $\left(X_{e}\right)$ and calorieprotein ratio of diet $\left(\mathrm{X}_{\mathrm{C}}\right)$ are given by the equations.

$$
\begin{aligned}
& \mathrm{Y}=0.23 \mathrm{X}_{\mathrm{p}} \quad-\quad 1.03 \text {, } \\
& \mathrm{Y}=2.17 \mathrm{X}_{\mathrm{e}} \quad-\quad 3.27 \text { and } \\
& \mathrm{Y}=-0.16 \mathrm{X}_{\mathrm{c}} \quad-\quad 5.54 \text {, respec- }
\end{aligned}
$$

The coefficients of determination $\left(R^{2}\right)$ for the three relationships are $0.60,0.20$ and 0.34 , respectively, indicating the proportion of variability in egg number attributable to percent protein, energy and calorie-protein ratio, respectively, if each factor was operating independently. The multiple regression relating egg production to the three factors is given by

$$
\begin{gathered}
\mathrm{Y}=0.1673 \mathrm{X}_{1}-0.0107 \mathrm{X}_{2} \\
-0.000000 \mathrm{IX}_{3}-11 \times 10^{-7}
\end{gathered}
$$

where $\mathrm{X}_{1}=$ percent protein in diet, $(\mathrm{SE}$ $=0.0107$ )

$\mathrm{X}_{2}=$ Metabolisable Energy in $\mathrm{Mcal} / \mathrm{kg},(\mathrm{SE}=0.0032)$

$\mathrm{X}_{3}=$ Calorie-Protein ratio in $\mathrm{Kcal} / \mathrm{g}$ protein (S.E. $4.9 \times 10^{-4}$ ).

The combined coefficient of determination $\left(R^{2}\right)$ is 0.35 . This indicates that the combined dietary factor accounted for $35 \%$ of the total variability in egg production, although the contribution of the calorie-protein ratio was negligible.

The results obtained in this study reinforce the conclusions of Chawla et al (1976) that egg production in summer months increased with increased protein levels up to $18.5 \%$, while further increases up to $21.6 \%$ did not yield any significant improvements. On the basis of their results, they recommended a separate protein level of $19 \%$ in the summer and $15 \%$ in the winter. The results of this study are also in agreement with the report of Khoo
(1977) who suggested that a diet of $190 \mathrm{~g}$ protein per $\mathrm{kg}$ supported the highes egg production and egg mass and that feed efficiency was enhanced by using a $11.7 \mathrm{MJ}$ $\mathrm{ME} / 190 \mathrm{~g} / \mathrm{kg}$ diets. It is therefore apparent that higher protein levels are required for layers raised in the tropics than the N.R.C. recommended level of $15 \%$. These results are in complete disagreement with the suggestion by Olomu (1979) that layers in tropical environments may have requirements lower than $16 \%$ protein. Furthermore, while fairly close estimations of the desired increases in protein levels can be derived from intake by applying a factor of $16.5 \mathrm{~g} \mathrm{x} 100$, the estimate of energy intake in the diet by that simple procedure is not accurate. A separate determination and development of nutrient levels for layers in the tropics would therefore appear necessary.

It is concluded from this study that:

1. A diet containing $18.45 \%$ protein, $3.03 \mathrm{Mcal} / \mathrm{kg} \mathrm{ME}$ and $16.42 \mathrm{Kcal} / \mathrm{g}$ protein ratio is most ideal for optimum egg production, egg mass and highest revenue-cost ratio in layers raised in the tropics.

2. Layers raised under tropical conditions cannot attain daily nutrient intake equivalent to the N.R.C. (1977) reccommendation of 165 protein per day or 313.5 Kcal per day due to depressed feed consumption.

3. Adjustments of protein levels from intake figures may not provide the desired optimum levels and ratios of these nutrients, therefore the need for a separate set of standards for tropical stock is indicated.

\section{REFERENCES}

Association of Official Analytical Chemists A.O.A.C. 1970 . 


\section{OBIOHA ET $A L$}

Brown, W.O., Waring, J. and SQUANCE, H. 1963. In: Brown, W.O. 1964. High Energy Diets for Poultry U.S. Feed Grains Council Tech. Publ.

Chawla, J.S., Lodhi, G.N. and ICHHPONA.NI, J.S. 1967. The Protein Requirement of Laying Pullets with Changing Seasons in the Tropics. Poult. Sci. 17: 275-283.

Davis, R.H., HASSAN, O.E.M. and SYKES, A.H. 1973. Energy Utilization in the Laying Hen in Relation to Ambient temperature. J. Agric. Sci. Cambr. 81: 173-177.

HARMS, R.H. and W ALdRouP, P.W. 1962. Strain Differences in the Protein Requirement of Laying Hens. Poult. Sci. 41: 1985-1987.

KHoO, T.H. 1977. Effects of Nutrient Concentration and Dietary Presentation on Performance of Dwarf Hens. Br. Poult. Sci. 18: 223-226.
LILLIE, R.J. and Denton, C.A. 1966. Effect of Nutrient Restriction on White Leghorns in the Grower and Subsequent Layer Periods. Poult. Sci. 45(2): 810-818.

National Research Council - N.R.C. 1977. Nutrient Requirements of Poultry. No. 1. Seventh Revised Edition.

OlomU, J.M. 1979. Poultry Nutrition Research Its Contribution to National Poultry Industry. 2 Production Standards for Poultry in Nigeria. Proc. 1st National Seminar on Poultry Production. A.B.U. Zaria Dec. 11-13, 1979. 269-283.

Oluyemi, J.A. and Fetuga, B. L. 1978. The Protein and Energy Requirements of Ducklings in the Tropics. Br. Poult. Sci. 19: 261-266.

Steel, R.G.D. and Torrie, J. H. 1960. The Principles and Procedures of Statistics. McGraw-Hill Book Co. Inc. N.Y. 